\title{
Effect of topography on tree species composition and volume of coarse woody debris in an Oriental beech (Fagus orientalis Lipsky) old growth forests, northern Iran
}

\author{
Kiomars Sefidi ${ }^{(1)}$, \\ Fariba Esfandiary Darabad ${ }^{(2)}$, \\ Mojtaba Azaryan ${ }^{(3)}$
}

\begin{abstract}
There is an emerging interest in the relationships between forest structure and topographic aspects. Still, such patterns have been scarcely studied in undisturbed mixed beech forests in northern Iran. We investigated the influence of topographical factors including aspect, slope degree, and landform index (LI) on the distribution of dominant tree species and coarse woody debris (CWD). Tree density and basal area were not significantly correlated with any of the measured parameters, except a moderate relation between basal area and $\mathrm{LI}(r=-0.376 ; P=0.029)$. Redundancy analysis (RDA) of the tree layer revealed a significant relationship between the measured environmental variables and species distributions. CWD volume showed significant negative correlation with percent canopy coverage and was highly correlated with slope. Density of CWD in decay class IV was significantly correlated with aspect and percent of canopy cover. Analyses of CWD distributions in relation to both living vegetation and topographic gradients showed a highly complex interplay of factors driving the distribution of CWD across the forest stands.
\end{abstract}

Keywords: Stand Structure, Physical Geography, Landform, Caspian Forest, Fagus orientalis

\section{Introduction}

Environmental factors impact vegetation patterns and species distribution, and play an important role in structuring plant communities across the landscape (Frelich 2002). In mountain ecosystems, topographic conditions can influence resource and moisture availability, and daily insolation, which are important factors for species distribution, plant growth and mortality patterns. Therefore, sites with different topographical features support different forest types (Small \& McCarthy 2002, Garcia et al. 2007).

Coarse woody debris (CWD) is generally considered as dead woody materials in various stages of decomposition, including fallen decaying stem and branches having a minimum diameter (or an equivalent cross-section) of $10 \mathrm{~cm}$ at the widest point (Enrong et al. 2006). Several recent studies contribute to better understanding the extent and role of CWD in forest ecosystems (Brunet \& Isacsson 2009, Fukasawa et al. 2010, Odor \& Van Hees 2004, Sefidi \& Etemad 2012). Dead woody debris provides rooting substrate and nurse logs for regeneration of plants (McAlister 1995, Christensen et al. 2005), facilitates nutrient cycling and energy flows through forest ecosystems (Huntington \& Ryan 1990, Huston 1996), maintains hydrology and soil retention capacities (Harmon et al. 1986), provides wildlife habitat, and increases biodiversity in forest ecosystems (Colak 2002, Hahn \& Christensen 2005, Sefidi \& Etemad 2015). CWD has been included in the list of improved European indicators for sustaina-
(1) Faculty of Agriculture Technology and Natural resources, University of Mohaghegh Ardabili, Ardabil (Iran); (2) Department of Physical Geography, University of Mohaghegh Ardabili, Ardabil (Iran); (3) College of Agriculture \& Natural Resources, University of Tehran, Tehran (Iran)

@ Kiomars Sefidi (kiomarssefidi@gmail.com)

Received: Jul 19, 2013 - Accepted: Nov 11, 2015

Citation: Sefidi K, Esfandiary Darabad F, Azarian M (2016). Effect of topography on tree species composition and volume of coarse woody debris in an Oriental beech (Fagus orientalis Lipsky) old growth forests, northern Iran. iForest 9: 658-665. - doi: 10.3832/ifor1080-008 [online 2016-03-17]

Communicated by: Emanuele Lingua ble forest management by the Ministerial Conference on the protection of forests in European countries (Butler \& Schlapfer 2004).

In the Oriental beech (Fagus orientalis Lipsky) old-growth forests along the Caspian sea, CWD volume varies according to successional stage, site conditions and management history. An important feature of natural forests of this region is their high amounts of dead wood in all stages of decay and the high proportions of old living trees with dead parts (Moradi et al. 2012, Sefidi \& Marvie-Mohadjer 2010), with fairly high amount of coarse woody debris (on average, $51 \mathrm{~m}^{3}$ ha $^{-1}$ - Sefidi \& MarvieMohadjer 2010). Sefidi et al. (2013) for the Hyrcanian beech-dominated forests, recorded volume of coarse and fine woody debris of 15 and $10 \mathrm{~m}^{3}$ ha-1, respectively. Amanzadeh et al. (2013) in a study carried out in northern Iran reported standing and fallen dead wood volume ranging from 9.1-24.7 and $7.5-29 \mathrm{~m}^{3} \mathrm{ha}^{-1}$, respectively. In contrast, oriental beech stands managed for timber production displayed a lower volume of coarse woody debris, with an average of 23 $\mathrm{m}^{3} \mathrm{ha}^{-1}$ (Atici et al. 2008). These studies focused on the CWD amount in different successional stages and forest associations, but the influence of topographic gradient on the distribution of woody debris in forest stands had not been investigated. In northern forests, insufficient knowledge and scarce quantitative information about amount and quality of dead wood negatively influence forest management plans. 


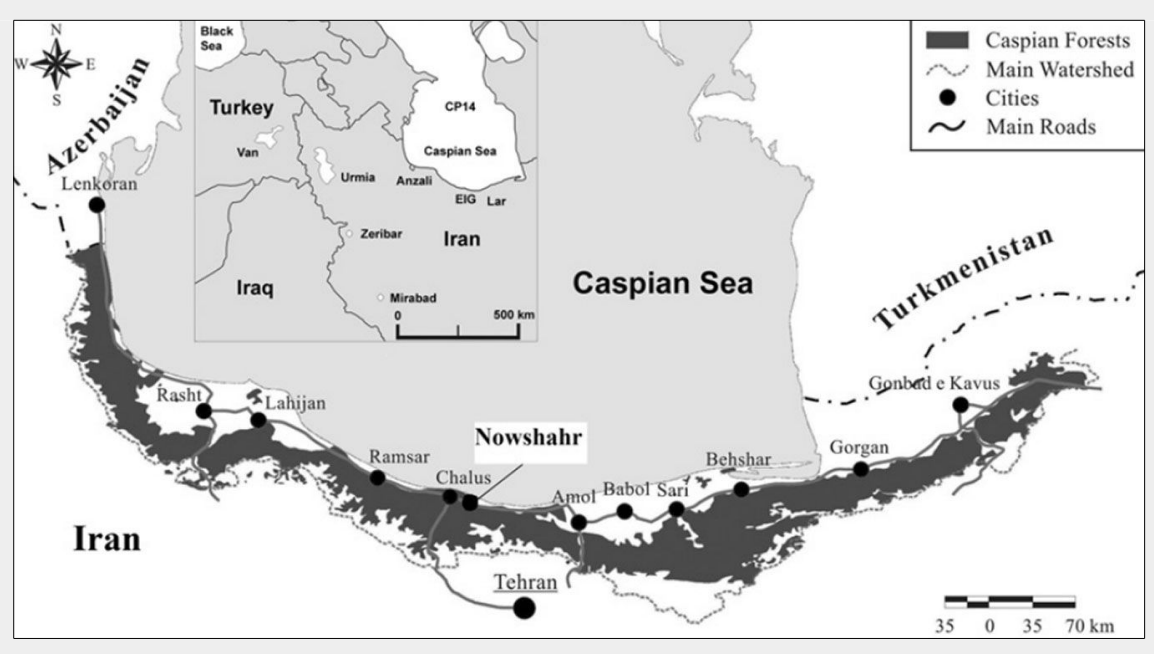

Fig. 1 - The distribution of Caspian forests (dark grey) in the north of Iran (modified from Nosrati et al. 2005). The study area is indicated in the white box.

In order to manage uneven-aged forest stands using the single selection method, it is of great importance to understand the factors that affect the dead wood pool dynamics and the distribution of CWD in topographically dissected area supporting specific forest stands, such as mountain beech forests in Western Asia (Burrascano et al. 2013), especially when woody debris is to be managed for maintenance of biodiversity and/or certain stand structural characteristics (Keddy \& Drummond 1996). In this stydy, we seek to quantify the effect of the topographic gradient on beech stand structure in the Caspian forest, although the relationship between woody vegetation and topographic gradients has been fairly well studied in beech stands of other northern Iranian regions (Eshaghi Rad \& Banj Shafiei 2010, Alavi et al. 2008).

Oriental beech is a shade-tolerant tree species covering north-facing slopes of Elborz Mountain, in contrast to oak-dominated stands highly distributed across the south-facing slopes of northern Iran (Sagheb-Talebi et al. 2014). The unique topographical position of beech stands in this area influence the formation and distribution of different forest vegetation types and coarse woody debris. Such stands, known as Caspian mixed forests, are characterized by minimal anthropogenic disturbances, the presence of old trees near their maximum longevity, large amounts of standing and lying deadwood, and a heterogeneous stand structure, both horizontally and vertically.

The main aim of this research was to quantify the influence of topographical factors on species composition, and quantity and quality of coarse woody debris in natural and undisturbed areas of the Caspian mixed forests.

\section{Methods}

Study area

The study was conducted in the Goraz- bon section of the Kheyrud Experimental Forest (northern Iran), which is owned and managed by the University of Tehran for education, research, and conservation purposes (Fig. 1). The forest covers a total area of almost 8000 ha and ranges from $36^{\circ} 27^{\prime}$ $\mathrm{N}$ to $36^{\circ} 40^{\prime} \mathrm{N}$ of latitude and from $51^{\circ} 32^{\prime} \mathrm{E}$ to $51^{\circ} 43^{\prime} \mathrm{E}$ of longitude (Nosrati et al. 2005). The climate is sub-Mediterranean with a mean annual temperature of $9{ }^{\circ} \mathrm{C}$ and total annual precipitation of $1380 \mathrm{~mm}$ (Marvie-Mohadjer 1976). Selected forest communities are established on plateaus or fairly inclined slopes which are dominated by moderately acidic to alkaline brown soils with deep, organic A-horizons, limestone bedrock, and a surface largely free of rocks (Dewan \& Famouri 1961). Most stands are uneven-aged where new seedling establishment occurs within canopy gaps (Marvie-Mohadjer 1976). The undisturbed mature beech stands were classified as a climax forest and represent a regional example of old-growth forests with no historical cutting or harvesting of trees (Sefidi 2012). The elevation of this area ranges between 1000-2000 $\mathrm{m}$ a.s.l.. Oriental beech and oriental hornbeam (Carpinus orientalis Miller) are the major species, with Persian maple (Acer velutinum Boiss), Cappadocian maple (Acer cappadocicum Gled.), largeleaf lime tree (Tilia platyphyllos Scop), Siberian elm (Zelkova carpinifolia (Pall.) Dipp), Caucasian Alder (Alnus subcordata C.A.M), Wych elm (Ulmus glabra Hudson), sweet cherry (Prunus avium L.), common yew (Taxus baccata L.), and wild service tree (Sorbus torminalis L.) as less common, but still important part of the forest composition (Sagheb-Talebi et al. 2014).

\section{Field sampling}

Data collection and field inventories took place during the summer of 2012. To characterize the coarse woody debris within stands, a $50 \times 50$ meter regular grid of sampling points was established within a natural beech stand, and 0.1-ha circular plots were set at 35 sampling points randomly selected using a systematic random sampling technique, with the aim of equally represent a wide variety of topographical factors (Marvie-Mohadjer 2005, Sefidi et al. 2014). Potential plot locations were identified using a topographic map (Anonymous 2010). Each plot was established in order to have oriental beech as the dominant species in the canopy, and the CWD element closer to the intersection point of the grid was considered the plot center. CWD was defined as decaying dead trees or large branches with a diameter $>10 \mathrm{~cm}$ regardless to their length. To avoid any edge effects, plots were located at least $100 \mathrm{~m}$ away from the forest border and trails. Because of the high degree of complexity in the old growth beech stands, the plot size of 0.1 ha was chosen as larger plots often spread across more than one topographic feature (Rubino \& McCarthy 2003, Sefidi 2012).

In each plot, we measured percent slope, aspect and land form. Instead of using descriptive categories (such as ridge, midslope, and valley), we quantified land form as a land form index ( $\mathrm{LI}$ ) by calculating the mean slope from the plot center to the topographic horizon every 45 degrees (8 total measurements) around the plot center using clinometer and compass (McNab 1992, Rubino \& McCarthy 2003). The eight measurements were then averaged to obtain a single LI value for each plot. The use of the land form index (LI, dimensionless) instead of descriptive categories (ridge, mid-slope, valley) facilitated statistical analyses and avoided classification problems. In fact, using this index the effects of distance and height of landforms are compensated, e.g., a low, nearby ridge and ta high, distant ridge could have the same effect on LI, though obviously their ecological influence could differ (McNab 1992).

The percent of canopy coverage was visually estimated in each plot and classified according to three canopy coverage classes: (I) canopy coverage > 75\%; (II) coverage between 50 and $75 \%$; and (III) canopy coverage < 50\% (Marvie-Mohadjer 2005).

In each plot, all woody stems greater than $7.5 \mathrm{~cm}$ DBH were identified, and their DBH recorded. For each piece of CWD, we recorded species, total length, type (log, snag, or stump), diameter at both ends, diameter at the midpoint (for stumps only the diameter at the midpoint was recorded), and decay class. For species not identified in the field, a small section of wood was excised and identified later in the lab based on its macro- and microscopic characteristics (Parsapajoh \& Schweingruber 1994). Lengths and diameters were taken at the edge of the plot boundary if the log extended outside of the plot. The diameters of logs, snags and stumps were measured using a caliper; however, for taller snags, top diameters were estimated visually as suggested by Harmon \& Sexton (1996). Decay classes were defined accor- 
ding to Albrecht (1990) as Class 1 (recently dead), Class 2 (bark loose with some decay in the sapwood), Class 3 (decay obvious throughout the secondary xylem) and Class 4 (woody debris mixing with soil, little structural integrity). Thus, according to these definitions a snag could never be identified as Class 4.

The Newton's formula was used to calculate the log volume (Harmon \& Sexton 1996 - eqn. 1):

$$
V=\frac{L\left(A_{b}+4 A_{m}+A-t\right)}{6}
$$

where $V$ is the volume in $\mathrm{m}^{3}, L$ the length, and $A_{\mathrm{b}}, A_{\mathrm{m}}$ and $A_{\mathrm{t}}$ are the cross-sectional area at the base, middle, and top, respectively. The volume for snags and stumps was calculated as (eqn. 2):

$$
V=A m \cdot L
$$

where $V$ is the volume in $\mathrm{m}^{3}, A_{\mathrm{m}}$ is the cross-sectional area at the middle of the length, and $L$ is the length.

\section{Data analysis}

Species basal area, density and relative importance values were calculated in each plot for both living and dead trees. Relative ecological importance value (RIV) was calculated for each species by averaging the relative density (number of stems), and the relative dominance (basal area) values. RIV ranks tree species within a site not only based upon the total number of individual trees but also based on the total amount of forest area occupied by the tree species. This index indicates how commonly a species occurs across the entire forest (Curtis \& McIntosh 1951). Coarse woody debris RIV was calculated for each species in each plot by averaging the sum of each relative density and relative volume of CWD (Rubino \& McCarthy 2003).

Pearson's product-moment correlation analysis was used to investigate the relationships between basal area (volume for (WD), density, and RIV values for trees and CWD and plot parameters (LI, slope aspect, percent slope, and percent canopy cover).

We utilized a multivariate approach to investigate the relationships between live and dead trees distributions and plot parameters. A preliminary detrended correspondence analysis (DCA) was performed to assess the gradient length of the species data for each of the structural layers. DCA revealed the presence of short (linear) gradients, so we utilized redundancy analysis to assess the gradient length of the species data for each of the three structural layers (Leps \& Smilauer 2005, Fortin \& Dale 2005, Ter Braak \& Smilauer 1998).

Redundancy analysis (RDA) is a method of direct gradient analysis consisting in a constrained linear method of canonical ordination that allows species-environment relationships to be explored. RDA methods try to find values of a new variable that represents the best predictor for the va- lues of all the species as a response variables.

RDA was performed separately for living trees and CWD using species RIV values. Three different RDA analyses were performed. In the first one, environmental and stand (living tree component) parameters were plotted, with no distinction between species. In the second one, environmental and stand parameters (explanatory variables) and RIV of species in the living tree component (response variables) were plotted. In the third one, environmental and stand parameters (explanatory variables) and RIV of species in the CWD component (response variables) were plotted. RDA with tree species data was performed using percent slope, transformed slope aspect, percent canopy cover and land form index. Explanatory variables included importance value of tree species, basal area, density of tree species, crown canopy percent, slope aspect and percentage and tree species in two RDA. Prior to bivariate and multivariate analyses, normality of species distributions and plot parameters were assessed using Kolmogorov-Smirnov normality tests, and appropriate transformations were performed to satisfy normality assumptions. Pearson correlation test was used to investigate the relationship among topographical variables and stand characteristics including stand density, basal area and CWD.

For slope aspect categories as nominal data set, the non-parametric Spearman's rank correlation procedure (Zar 1999) was used instead of the Pearson's productmoment correlations. Multivariate analyses were performed using CANOCO version 4.5 (Leps \& Smilauer 2005). The significance

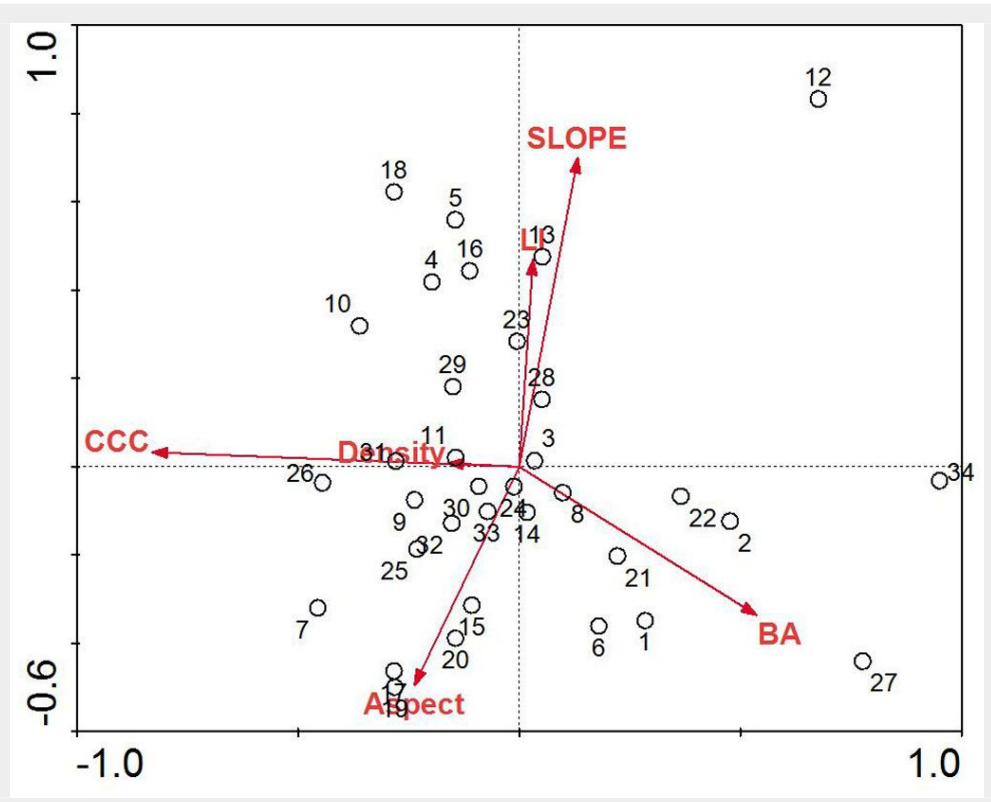

Fig. 2 - RDA biplot of sampling plots and environmental parameters for mixed beech stands, northern Iran. Arrows indicate environmental parameters used in the creation of the biplot: (BA): basal area of trees; (Density): density of trees; (Aspect): transformed slope aspect; (CCC): percent canopy cover; (LI): land form index; (Slope): percent slope.
Tab. 1 - Physiographical characteristics of the study site within old growth $F$.

\begin{tabular}{lll}
\hline Characteristic & Parameter & Value (\%) \\
\hline Percent & Mean & $19.5 \pm 1.8$ \\
slope & Min & 7 \\
& Max & 35 \\
\hline Land form & Mean & $11.8 \pm 0.8$ \\
index & Min & 5.3 \\
& Max & 28.3 \\
\hline Crown Canopy & Mean & $75.3 \pm 3.1$ \\
Coverage & Min & 35 \\
& Max & 95 \\
\hline
\end{tabular}

level for correlation analysis was set at a significance level of $\alpha=0.05$.

\section{Results}

\section{Plots}

Individual plot parameters varied throughout sampling plots (Tab. 1). The mean DBH in sampling plots was $41.58 \pm 1.2 \mathrm{~cm}$, while mean CWD volume was $74.6 \pm 18.1 \mathrm{~m}^{3}$ $\mathrm{ha}^{-1}$. Distribution patterns of sampling plots along the first two extracted canonical axes differed throughout the study site with respect to environmental parameters (Fig. 2). We performed a one-way ANOVA as an exploratory test to determine if differences in standard slope position categories (ridge, mid slope, valley) were detectable using LI. We found a significant difference between the three categories ( $F$ $=4.71, p=0.016)$, and post-hoc analysis (Bonferroni's multiple comparison test) orientalis forests of northern Iran. 
Tab. 2 - Mean ( $\pm \mathrm{SE}$ ) density (stems ha-1), basal area $\left(B A, m^{2} h a^{-1}\right)$, relative density (RELDEN), relative basal area (RELBA), and RIV of trees $(\mathrm{dbh}>7.5 \mathrm{~cm})$ in the oriental beech forests of northern Iran.

\begin{tabular}{lcrrrr}
\hline Species & Density & \multicolumn{1}{c}{ BA } & \multicolumn{1}{c}{ RELDEN } & \multicolumn{1}{c}{ RELBA } & \multicolumn{1}{c}{ RIV } \\
\hline Fagus orientalis & $98.8 \pm 10.5$ & $23.9 \pm 2.2$ & $54.9 \pm 5.6$ & $61.3 \pm 5.1$ & $58.1 \pm 5.1$ \\
Carpinus betulus & $70.8 \pm 15.5$ & $5.9 \pm 1.1$ & $30.3 \pm 5.5$ & $17.1 \pm 3.3$ & $23.6 \pm 4.3$ \\
Acer velutinum & $13.2 \pm 3.1$ & $3.7 \pm 0.8$ & $7.4 \pm 1.8$ & $9.2 \pm 2.4$ & $8.3 \pm 1.7$ \\
Alnus subcordata & $11.5 \pm 2.5$ & $5.4 \pm 1.4$ & $6.1 \pm 1.1$ & $11.4 \pm 2.8$ & $8.7 \pm 1.9$ \\
Quercus castaneifolia & $0.6 \pm 0.2$ & $0.3 \pm 0.3$ & $0.3 \pm 0.2$ & $0.6 \pm 0.5$ & $0.4 \pm 0.3$ \\
Other species & $0.3 \pm 0.2$ & $0.2 \pm 0.1$ & $0.2 \pm 0.1$ & $0.3 \pm 0.2$ & $0.3 \pm 0.1$ \\
Total, all plots & $195.2 \pm 10.4$ & $39.6 \pm 2.3$ & - & - & - \\
\hline
\end{tabular}

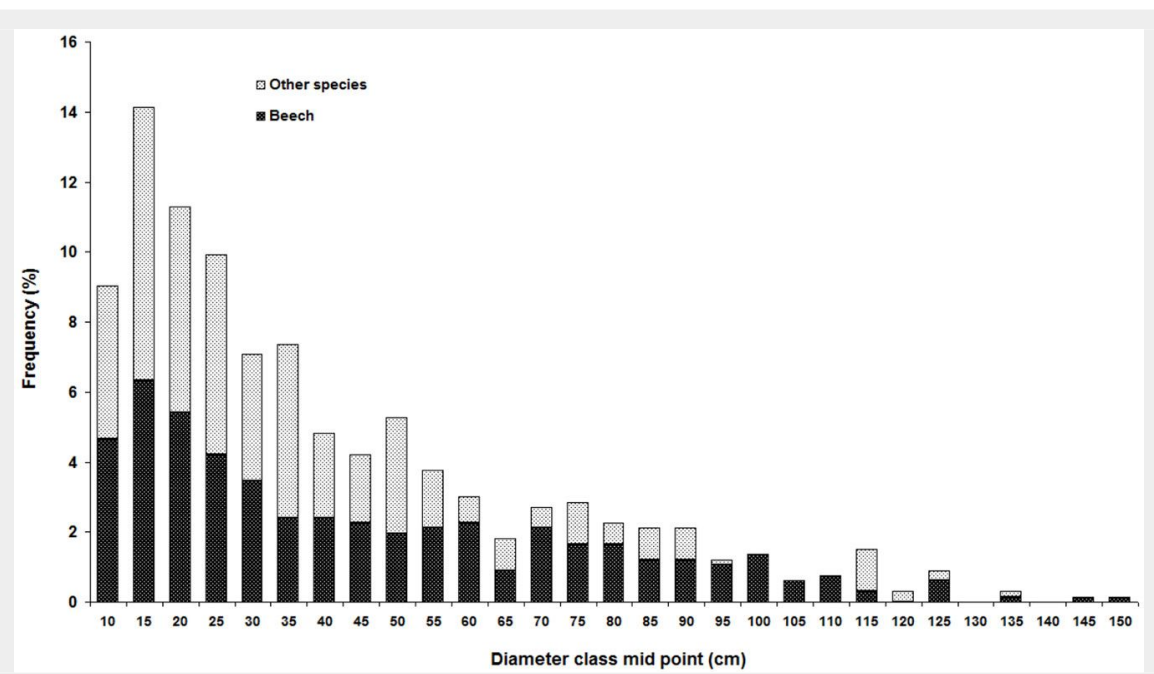

Fig. 3 - Diameter distribution of mixed beech stands in northern Iran. Tree species are distinguished into two groups: F. orientalis (black) and all other tree species (grey).

Tab. 3 - Correlation test results for stand density, basal area and CWD in relation to the topographical variables.

\begin{tabular}{lcccccc}
\hline \multirow{2}{*}{ Variables } & \multicolumn{2}{c}{$\begin{array}{c}\text { Density } \\
(\mathbf{N ~ h a}\end{array}$} & \multicolumn{2}{c}{$\begin{array}{c}\text { Basal area } \\
\left(\mathbf{m}^{2} \mathbf{h a}^{-1}\right)\end{array}$} & \multicolumn{2}{c}{$\begin{array}{c}\text { CWD } \\
\left(\mathbf{m}^{3} \mathbf{h a}^{-1}\right)\end{array}$} \\
\cline { 2 - 8 } & $\mathbf{r}$ & $\mathbf{P}$ & $\mathbf{r}$ & $\mathbf{P}$ & $\mathbf{r}$ & $\mathbf{P}$ \\
\hline Percent slope & 0.025 & 0.886 & -0.284 & 0.128 & 0.922 & $<0.001$ \\
Slope aspect & 0.012 & 0.945 & -0.306 & 0.079 & 0.253 & 0.128 \\
Land form index & 0.055 & 0.757 & -0.376 & 0.029 & 0.307 & 0.091 \\
\hline
\end{tabular}

revealed that all the three groups were significantly different (Rubino \& McCarthy 2003).

\section{Trees}

In the sampling plots, Fagus orientalis had the highest mean density, basal area, and RIV, followed by Carpinus betulus, Alnus subcordata, Acer velutinum and Tilia begonifolia (Tab. 2). Diameter distribution showed a reverse J-shape curve (Fig. 3). Tree density was not related to site parameters, but there was a significant correlation between basal area and land form index (Tab. 3).

RDA of the tree layer revealed a significant relationship between the environmental variables and species distributions on the first canonical axis $(F=36.72, p<0.001)$ and all four canonical axes $(F=8.17, p<$ o.001). The environmental variables explained $63.3 \%$ of the variation in species distributions on the first two axes. Examination of the inter-set (correlation between species axes and environmental variables) and intra-set (correlation between environmental axes and environmental variables) correlation values revealed that both species axis 1 and environmental axis 1 were correlated with $\mathrm{LI}(r=0.25$ and 0.30 , respectively), although the strength of the correlation was small. In contrast, species axis 2 and environmental axis 2 were highly correlated with aspect $(r=0.49$ and 0.73 , respectively).

Species distributions in the multi-dimensional space were consistent with changes in individual species presence and habitat affinities (Fig. 2). For example, mesophytic species such as $F$. orientalis and $T$. begonifolia (Sagheb-Talebi et al. 2014) were found on the left side of the RDA biplot (northerly aspects and high LI scores, valleys). Additionally, $C$. betulus was found on the right side of the biplot; this is consistent

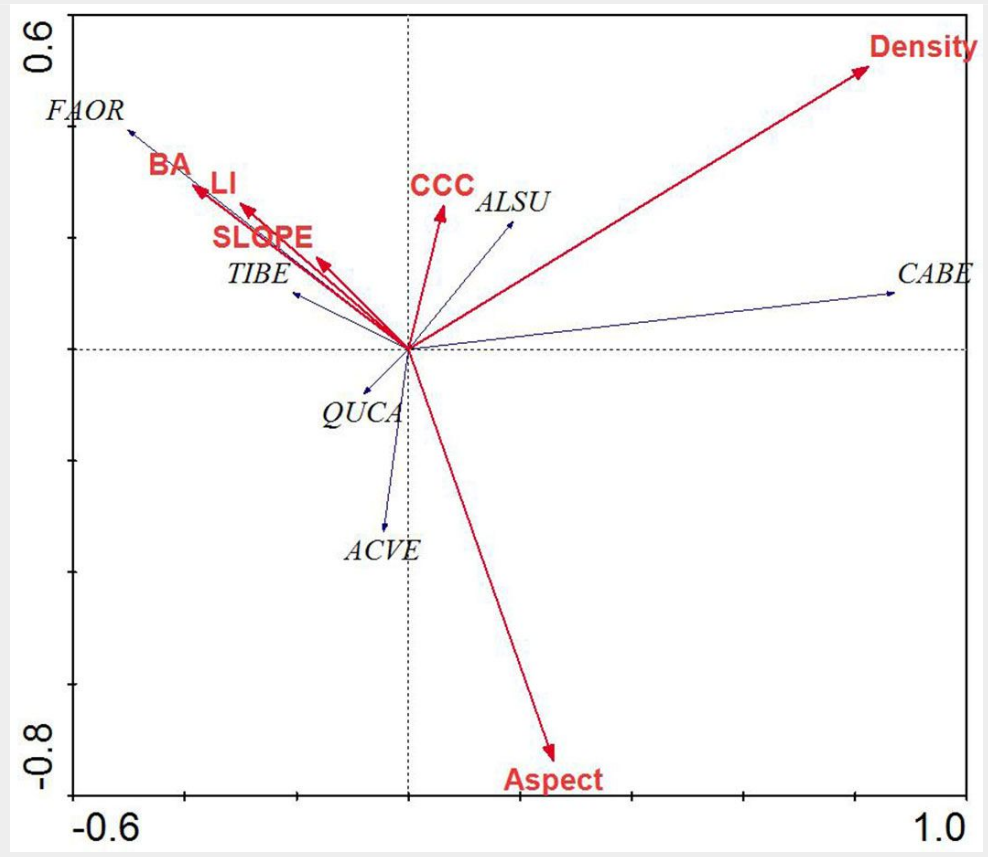

Fig. 4 - Redundancy analysis biplot of tree species and environmental parameters for mixed beech stands, northern Iran. Species name abbreviations are: (FAOR): Fagus orientalis; (TIBE): Tilia begonifolia; (ALSU): Alnus subcordata; (CABE): Carpinus betulus; (QUCA): Quercus castaneifolia; (ACVE): Acer velutinum. Arrows indicate the environmental parameters used in the creation of the biplot. (BA): basal area of trees; (Density): density of trees (ASPECT): transformed slope aspect; (CCC): percent canopy cover; (LI): land form index; (SLOPE): percent slope. 
with its distributions reaching maxima on more dry and exposed slope aspects and slope position (southerly and ridge - Fig. 4).

\section{Coarse woody debris}

Four major trees species encompass the highest amount of CWD in the sampling plots (Tab. 4). The most frequently CWD species were oriental beech, which was found in $65 \%$ of sampling plots, followed by Carpinus betulus (29\%). F. orientalis had the highest and $C$. betulus had the second highest mean density, volume, relative density, relative volume, and RIV of all CWD (Tab. 4).

Correlation analysis revealed no significant relationships between CWD volume and $\mathrm{LI}$ and slope aspect. CWD volume was significantly negatively correlated with percent canopy cover $(r=0.423, p=0.012)$ and highly correlated with slope $(r=0.922, p<$ 0.001). The CWD volume $\left(\mathrm{m}^{3} \mathrm{ha}^{-1}\right)$ was significantly correlated with tree basal area $(r$ $=0.504, p=0.002)$.

Tree density $\left(\mathrm{N} \mathrm{ha}^{-1}\right)$ and CWD volume $\left(\mathrm{m}^{3}\right.$ $h^{-1}$ ) in each decay classes was not correlated with plot parameters, except class IV CWD density that was significantly correlated with aspect $(r=0.296, p=0.044)$ and the percentage of crown canopy coverage $(r=0.335, p=0.026)$.

The RDA of CWD data revealed a significant relationship between the CWD distributions and the environmental variables for the first axis $(F=6.97, p=0.044)$ but not for all of the four extracted axes $(F=$ $1.432, p=0.142)$. The environmental variables explained $22.5 \%$ of the variation in the species data on the first two axes (Fig. 5).

Species axis 1 and environmental axis 1 were most highly negatively correlated with canopy cover percent $(r=0.511$ and 0.829 , respectively), while species axis 2 correlated with parameters, but environmental axis 2 was most highly correlated with slope and aspect $(r=0.701$ and 0.469 , respectively).

\section{Discussion}

Based on our results, the distribution of woody species and CWD in the old growth oriental beech-dominated forest stands are influenced by topographic gradients. Natural stands in the mountain beech forests of northern Iran have a high stocking volume and basal area (Moradi et al. 2012). The presence of over-mature beech trees with diameter $>200 \mathrm{~cm}$ increased the mean basal area (39.6 $\mathrm{m}^{2} \mathrm{ha}^{-1}$ ). Sefidi (2012) reported a mean basal area ranging $18-46 \mathrm{~m}^{2}$ $\mathrm{ha}^{-1}$ in a 75 ha beech forest in the north of Iran.

Different results were reported for primeval beech forests in the eastern Europe. Popescu-Zeletin \& Dissescu (1967) reported a mean basal area of $17-50 \mathrm{~m}^{2} \mathrm{ha}^{-1}$ for a Carpathian beech forest, Urban et al. (2010) a mean value of $33.8-48.2 \mathrm{~m}^{2} \mathrm{ha}^{-1}$ in a mixed beech stands in the east of the Czech Republic, Hobi et al. (2015) a value of $36.3 \pm 0.8 \mathrm{~m}^{2} \mathrm{ha}^{-1}$ in the southern slopes of

Tab. 4 - Mean ( $\pm \mathrm{SE}$ ) density (stems ha-1), volume $\left(\mathrm{m}^{3} \mathrm{ha}^{-1}\right)$, and relative density (RELDEN), relative volume (RELVOL) of CWD $(\mathrm{dbh}>10 \mathrm{~cm})$ in the oriental beech forests, Northern Iran

\begin{tabular}{lccccc}
\hline Species & Density & Volume & RELDEN & RELVOL & RIV \\
\hline Fagus orientalis & $6.7 \pm 1$ & $44.6 \pm 15.7$ & $51.9 \pm 7.6$ & $56.3 \pm 8.1$ & $54.1 \pm 7.8$ \\
Carpinus betulus & $2.9 \pm 0.7$ & $4.3 \pm 2.8$ & $20.3 \pm 6.5$ & $18.9 \pm 6.3$ & $19.8 \pm 6.2$ \\
Acer velutinum & $2.3 \pm 0.7$ & $17.2 \pm 8.8$ & $16.4 \pm 5.8$ & $15.2 \pm 5.4$ & $16.1 \pm 5.7$ \\
Alnus subcordata & $11.5 \pm 2.5$ & $8.4 \pm 5.4$ & $10.1 \pm 5.1$ & $9.4 \pm 4.8$ & $9.9 \pm 5.1$ \\
Other species & 0 & 0 & 0 & 0 & 0 \\
Total, all plots & $13.2 \pm 1.2$ & $74.6 \pm 18.1$ & - & - & - \\
\hline
\end{tabular}

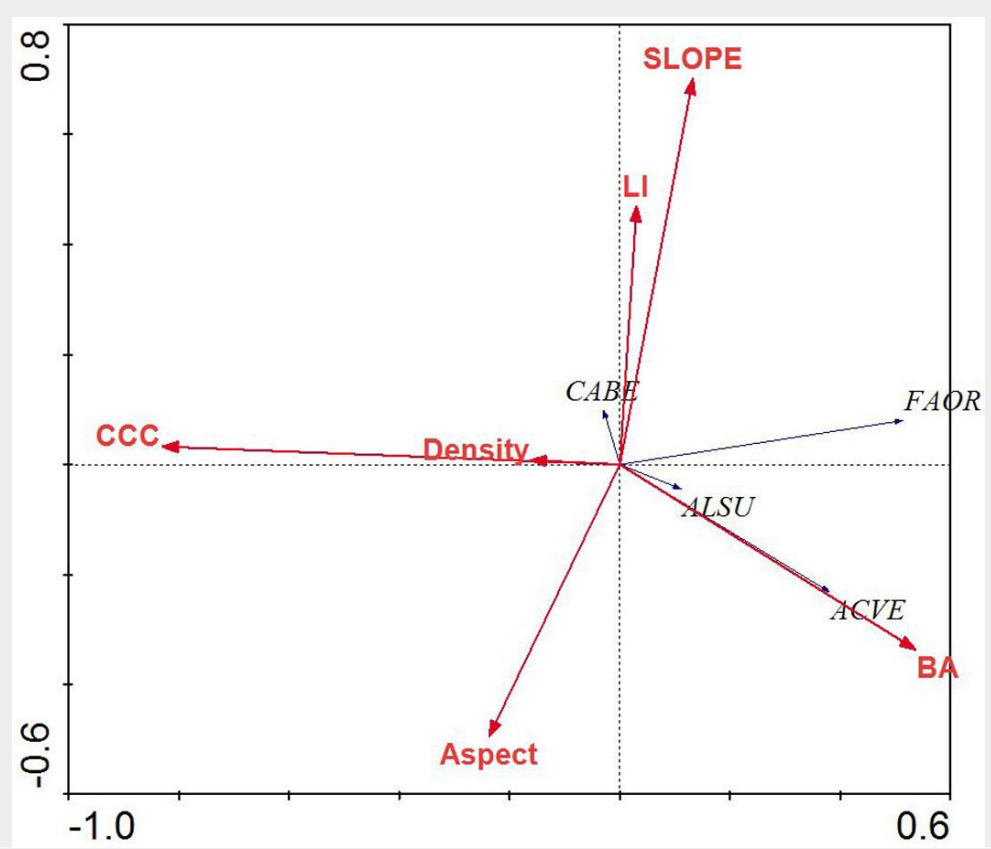

Fig. 5 - RDA biplot of coarse woody debris species and environmental parameters for mixed beech stands, northern Iran. Species name abbreviations are: (FAOR): Fagus orientalis; (TIBE): Tilia begonifolia: (ALSU): Alnus subcordata; (CABE): Carpinus betulus; (QUCA): Quercus castaneifolia; (ACVE): Acer velutinum. Arrows indicate environmental parameters used in the creation of the biplot. (BA): basal area of trees; (Density): density of trees; (Aspect): transformed slope aspect; (CCC): percent canopy cover; (LI): land form index; (SLOPE): percent slope.

the Carpathians in southwest Ukraine, and Petritan et al. (2012) an average basal area of $47.3 \mathrm{~m}^{2} \mathrm{ha}^{-1}$ in the Runcu-Grosi Natural Reserve in western Romania. The main reason for the aforementioned differences in basal area between Iranian and European mixed beech forests is that $F$. sylvatica is commonly mixed with different species such as silver fir (Popescu-Zeletin \& Dissescu 1967) and sessile oak (Petritan et al. 2014), that contribute to a high proportion of forest stand volume. In contrast, oriental beech in the Iranian forests is mainly mixed with European hornbeam in the understory, which does not represent a high percentage of the total standing volume (Sagheb-Talebi et al. 2014, Sefidi et al. 2014). Moreover, the productivity and sitespecific environmental factors can also influence stand basal area, thus accounting for the above differences.

Tree species distribution differed throughout the study site with respect to density and basal area. Mesophytic and shade tolerant species such as oriental beech were found with greater frequency on northerly aspects and lower-slope positions, while more xerophytic species such as hornbeam showed a higher frequency on drier, more exposed positions. F. orientalis is a shade tolerant and major canopy layer species, with greater mean basal area, relative basal area, and RIV than all other tree species (Tab. 1).

Oriental beech also showed a high volume and density of living and dead trees. In this study we found a mean CWD volume of $74.6 \pm 18.1 \mathrm{~m}^{3} \mathrm{ha}^{-1}$ with a range of 1.2 $136.1 \mathrm{~m}^{3} \mathrm{ha}^{-1}$, similar to several other studies carried out in the Iranian beech forests (Sefidi et al. 2013, Amanzadeh et al. 2013, Sefidi \& Marvie-Mohadjer 2010). Contrastingly, the total volume of dead timber at the Milesice Forest Reserve in the Czech Republic reached $324 \mathrm{~m}^{3} \mathrm{ha}^{-1}$ (Vrska et al. 2001), that was higher than our findings. Moreover, Hobi et al. (2015) reported 135.9 $\pm 7.5 \mathrm{~m}^{3} \mathrm{ha}^{-1}$ of lying coarse woody debris in 
the Uholka-Shyrokyi Luh primeval forest in the southern slopes of the Carpathians. Differences in CWD amount between European and Oriental beech forest are likely determined by differences in the stand composition and structure. The coarse woody debris pool reflects the past stand conditions, specifically an earlier successional period when different species dominated the overstory - a condition that is particularly common in old-growth stands (McCarthy et al. 2001). Moreover, in the European forests beech is mixed with softwood trees such as fir that are missing in the Iranian beech stands. Differences in decomposition rate among species can account for variation in the overstory and dead wood composition (Rock et al. 2008).

The distribution pattern of CWD along the first two extracted canonical axes were similar to patterns of living tree distribution, and were most likely influenced by physiological characteristics of the individual species. For example, oriental beech and maple CWD was mainly found on mesic sites such as valleys or plots with northerly aspects. In contrast, European hornbeam was found on xeric southerly aspects and ridges.

The significant correlation between volume and density of CWD and percent slope of plots revealed that high slope areas have high volume and density of CWD. Accumulation of CWD in the lower slopes (i.e., negative correlation between dead wood volume and the percent of slope) was expected because of the mechanical stability of trees growing on steep slopes and gravity-driven process. Nevertheless, our results revealed a high accumulation of CWD on high slopes that can be explained by the relatively homogeneity of topographic conditions of the study site. The median value of slope across the study site was $18 \%$; this means that $50 \%$ of sampling plots were located in relatively lower slope positions. On steep slopes, CWD tend to drop to lower-slope positions, therefore a negative correlation between the percent of slope and accumulation of CWD in lower slopes was observed. The negative correlation between CWD accumulation and slope was also reported by Rubino \& McCarthy (2003). The same authors also showed that different ecological conditions can affect decomposition rates and dynamics of woody debris as well as accumulation of CWD. Furthermore, Alidadi (2013) reported that the decomposition of oriental beech CWD largely differs from that reported for European beech, as tree dimensions affect the dead wood pool within stands. Indeed, long-lived oriental beech trees can reach more than 2 meters in diameter at productive sites, and show a high amount of forest dead wood in the studied sites (Sefidi \& Etemad 2012, Moradi et al. 2012).

The influence of topography on forest stand composition has been demonstrated in North America (McCarthy et al. 1984, Rubino \& McCarthy 2003), and similar evi- dence was also reported in Europe (Garcia et al. 2007) and in Iran (Mohsennezhad et al. 2010, Valipour et al. 2013). In the Caspian region, the most productive sites are located on the northern slopes. Valipour et al. (2013) reported that physiographic characteristics (including steepness of slope and aspect) significantly affect the structure of the oak-dominated forests of western Iran in terms of density and diameter class distribution. The same authors found a greater CWD volume on more fertile north-facing slopes than on south-facing slopes. Moreover, in the north of Iran Alidadi et al. (2015) showed dead wood decomposition rates of $F$. orientalis and Carpinus betulus significantly different between north facing and south facing slopes (Alidadi 2013). In this study, slope aspect was not significantly correlated with CWD volume or density, despite an accumulation of CWD in north-facing slopes was expected. Indeed, warmer microclimatic conditions in southern aspects can enhance the CWD decay as a consequence of more intense insolation, higher air and soil temperatures (Barnes et al. 1997). Temperature affects decomposition rate, as microbial and invertebrate activity is higher at higher temperatures (Yang et al. 2010, Mackensen \& Bauhus 2003). It was demonstrated that an increase of $2{ }^{\circ} \mathrm{C}$ in temperature increases stem woody debris decay (expressed in density loss) by $9-55 \%$ (Yin 1999).

The successional status of stands (Goebel \& Hix 1997, Saniga \& Schütz 2002, Sefidi \& Marvie-Mohadjer 2010, Sefidi 2012), as well as the susceptibility to storm damage (Bruederle \& Stearns 1985) or to pathogens (Walters \& McCarthy 1997, McCarthy et al. 2001) are all factors affecting the accumulation of CWD. Banas et al. (2014) stated that ecological and social functions of forests have a slight influence on the amount of CWD. Conservation of biological diversity is one of the most important goals of forest management and dead trees as micro habitats have a key role in maintaining biodiversity in forest ecosystems (Kraus \& Krumm 2013). The analysis of the influence of topographical gradients on the dead wood pool is crucial for the development of conservation strategies and for better monitoring the biological diversity in the forest ecosystems.

Physiographic factors can significantly affect tree characteristics in the oak dominated forests in western Iran. In this area, the greatest tree diameter, total height and crown cover were found on the lower slopes, eastern and northern aspects and high altitudes (Valipour et al. 2013). Rubino \& McCarthy (2003) showed distribution of trees, saplings, and CWD varies across the fragmented landscape in oak dominated stands in southern Ohio forests. Similar results were reported for other forest types (McCarthy et al. 2001, Goebel \& Hix 1997, Rubino \& McCarthy 2003). In montane mixed forests in Italy, Castagneri et al. (2010) indicated elevation, basal area of li- ving trees and human impact as the most important factors influencing dead wood pool.

Knowledge on the spatial distribution of CWD in topographically dissected forest stands of the Caspian region is still limited. The evaluation of environmental factors influencing CWD distribution is necessary for a better management of coarse woody debris in beech mixed Caspian forests.

\section{Acknowledgements}

We would like to thank Prof. Dr. Namiranian, The president of the Kheyrud Experimental Forest in northern Iran which is owned and managed by the University of Tehran for education, research, and conservation. We are also grateful for the very detailed and constructive comments by two anonymous referees.

\section{References}

Alavi SJ, Amiri ZG, Marvie Mohadjer MR, Nouri Z (2008). Spatial distribution of Ulmus glabra in relation to physiographical parameters. Journal of Environment 43: 93-100.

Albrecht L (1990). Grundlagen, Ziele und Methodik der Waldökologischen Forschung in Naturwaldreservaten [Objectives and methods of forest ecological research in natural forest reserves]. Bayerisches Staatsministerium für $\mathrm{Er}$ nährung, Landwirtschaft und Forsten, Müchen, Germany, pp. 219. [in German]

Alidadi F, Sefidi K, Zahedi-Amiri G, Etemad V (2015). Carbon content of oriental beech (Fagus orientalis Lipsky) and hornbeam (Carpinus betulus) dead wood in the Caspian forest of Iran. Journal of Forestry Research (In press).

Alidadi F (2013). Decay dynamic of dead trees in mixed beech stands, Northern Iran. MSc. Thesis, Natural resources Faculty, University of Tehran, pp. 157.

Amanzadeh B, Sagheb-Talebi K, Foumani BS, Fadaie F, Camarero JJ, Band JC, Linares XX (2013). Spatial distribution and volume of dead wood in unmanaged caspian beech (Fagus orientalis) forests from northern Iran. Forests 4: 751-765. - doi: 10.3390/f4040751

Anonymous (2010). Forest management plan, Kheiroud Forest. University of Tehran, Tehran, Iran, pp. 350.

Atici E, Colak AH, Rotherham ID (2008). Coarse dead wood volume of managed Oriental beech (Fagus orientalis Lipsky) stands in Turkey. Investigacion Agraria: Sistemasy Recursos Forestales 17: 216-227. - doi: 10.5424/srf/2008173-01036

Banas J, Bujoczek L, Zieba S, Drozd M (2014). The effects of different types of management, functions, and characteristics of stands in Polish forests on the amount of coarse woody debris. European Journal of Forest Research 133: 1095-1107. - doi: 10.1007/s10342-014-0825-3 Barnes BV, Zak DR, Denton SR, Spurt SH (1997). Forest ecology ( $4^{\text {th }}$ edn). John Wiley \& Sons, New York, USA, pp. 774.

Bruederle LP, Stearns FW (1985). Ice storm damage to a southern Wisconsin mesic forest. Bulletin of the Torrey Botanical Club 112: 167175. - doi: $10.2307 / 2996413$

Brunet J, Isacsson G (2009). Restoration of beech forest for saproxylic beetles - effects of 
habitat fragmentation and substrate density on species diversity and distribution. Biodiversity and Conservation 18 (9): 2387-2404. - doi: 10.1007/s10531-009-9595-5

Burrascano S, Keeton WS, Sabatini FM, Blasi C (2013). Commonality and variability in the structural attributes of moist temperate old-growth forests: a global review. Forest Ecology and Management 291: 458-479. - doi: 10.1016/j.for eco.2012.11.020

Butler R, Schlapfer R (2004). Dead wood in managed forests: how much is enough? Schweizerische Zeitschrift für Forstwesen 155 (2): 31-37. - doi: 10.3188/szf.2004.0031

Castagneri D, Garbarino M, Berretti R, Motta R (2010). Site and stand effects on coarse woody debris in montane mixed forests of Eastern Italian Alps. Forest Ecology and Management 260: 1592-1598. - doi: 10.1016/j.foreco.2010.08.008 Christensen M, Hahn K, Mountford M, Odor P, Stadovar T, Rozenberg D, Diaci J, Mayer Winter P, Vrska S (2005). Dead wood in European beech forest reserves. Forest Ecology and Management 210: 267-282. - doi: 10.1016/j.foreco. 2005.02.032

Colak AH (2002). Dead wood and its role in nature conservation and forestry: a Turkish perspective. The Journal of Practical Ecology and Conservation 5 (1): 37-49.

Curtis JT, McIntosh RP (1951). An upland continuum in the prairie-forest border region of Wisconsin. Ecology 32: 476-496. - doi: 10.2307/ 1931725

Dewan ML, Famouri J (1961). Soil map of Iran. Food and Agriculture Organization of the United Nations, FAO, Rome, Italy.

Enrong Y, Xihua W, Jianjun H (2006). Concept and classification of coarse woody debris in forest ecosystems. Frontiers of Biology in China 1: (1) 76-84.

Eshaghi Rad J, Banj Shafiei A (2010). The distribution of ecological species groups in Fagetum communities of Caspian forests: determination of effective environmental factors. Flora 205: 721-722. - doi: 10.1016/j.flora.2010.04.015

Frelich LE (2002). Forest dynamics and disturbance regimes, study from every green and deciduous temperate forest. Cambridge University Press, New York, USA, pp. 287.

Fortin MJ, Dale MT (2005). Spatial analysis: a guide for ecologists. University Press, New York, USA, pp. 365.

Fukasawa Y, Osono T, Takeda H (2010). Beech log decomposition by wood-inhabiting fungi in a cool temperate forest floor: a quantitative analysis focused on the decay activity of a dominant basidomycete Omphalotus guepiniformis. Ecological Research 25: 959-966. - doi: 10.1007/ s11284-010-0720-4

Garcia M, Montane F, Pique J, Retana J (2007). Overstory structure and topographic gradients determining diversity and abundance of understory shrub species in temperate forests in central Pyrenees (NE Spain). Forest Ecology and Management 242: 391-397. - doi: 10.1016/j.for ec0.2007.01.056

Goebel PC, Hix DM (1997). Changes in the composition and structure of mixed-oak, secondgrowth forest ecosystems during the understory reinitiation stage of stand development. Ecoscience 4: 327-339.
Hahn K, Christensen M (2005). Dead wood in European forest reserves - a reference for forest management. In: "Monitoring and Indicators of Forest Biodiversity in Europe - From Ideas to Operationality" (Marchetti M ed). EFI proceedings 51: 181-191.

Harmon ME, Franklin JF, Swanson FJ, Sollins P, Gregory SV, Lattin JD, Anderson NH, Cline SP, Aumen NG, Sedell JR, Lienkaemper GW, Cromack Cummins K (1986). Ecology of coarse woody debris intemperate ecosystems. Advances in Ecological Research 15: 133-276. - doi: 10.1016/S0065-2504(08)60121-X

Harmon ME, Sexton J (1996). Guidelines for measurements of woody detritus in forest ecosystems. US LTER Publication 20, New York, USA, pp. 73.

Hobi ML, Commarmot B, Bugmann H (2015). Pattern and process in the largest primeval beech forest of Europe (Ukrainian Carpathians). Journal of Vegetation Science 26: 323-336. - doi: 10.1111/jvs.12234

Huston MA (1996). Models and management implications of coarse woody debris impacts on biodiversity. In: "Coarse Woody Debris in Southern Forests: Effects on Biodiversity" (McMinn JW, Crossley DA eds). USDA Forest Service, Athens, GA, USA, pp. 139-143.

Huntington TG, Ryan DF (1990). Whole-tree harvesting effect on soil nitrogen and carbon. Forest Ecology and Management 31: 193-204. - doi: 10.1016/0378-1127(90)90067-L

Kraus D, Krumm F (2013). Integrative approaches as an opportunity for the conservation of forest biodiversity. European Forest Institute, Joensuu, Finland, pp. 284.

Keddy PA, Drummond CG (1996). Ecological properties for the evaluation, management, and restoration of temperate deciduous forest ecosystems. Ecological Applications 6 (3): 748. doi: $10.2307 / 2269480$

Leps J, Smilauer P (2005). Multivariate analysis of ecological data using CANOCO. Cambridge University Press, New York, USA, pp. 269.

Mackensen J, Bauhus J (2003). Density loss and respiration rates in coarse woody debris of Pinus radiata, Eucalyptus regnans and Eucalyptus maculata. Soil Biology and Biochemistry 35 (1): 177-186. - doi: 10.1016/S0038-0717(02)002559

Marvie-Mohadjer MR (1976). Some qualitative characteristics of Iranian beech forests. Iranian Journal of Natural Resources 34: 77-96.

Marvie-Mohadjer MR (2005). Silviculture and forest tending. University of Tehran Press, Tehran, Iran, pp. 378.

McAlister S (1995). Species interactions and substrate specify among log-inhabiting bryophyte species. Ecology 76: 2184-2195. - doi: 10.2307/ 1941692

McCarthy BC, Vierheller TI, Wistendahl WA (1984). Species ordination of upper slope oakhickory stands of southeastern Ohio. Bulletin of the Torrey Botanical Club 111 (1): 56. - doi: 10.2307/2996211

McCarthy BC, Small CJ, Rubino DL (2001). Composition, structure and dynamics of Dysart Woods, an old-growth mixed mesophytic forest of southeastern Ohio. Forest Ecology and Management 140: 193-213. - doi: 10.1016/S03781127(00)00280-2
McNab WH (1992). A topographic index to quantify the effect of mesoscale landform on site productivity. Canadian Journal of Forest Research 23: 1100-1107. - doi: 10.1139/×93-140

Mohsennezhad M, Shokri M, Zal H, Jafarian Z (2010). The effects of soil properties and physiographic factors on plant communities distribution in Behrestagh Rangeland. Rangeland 4 (2): $262-275$.

Moradi M, Marvie Mohadjer MR, Sefidi K, Zobiri M, Omidi A (2012). Over matured beech trees (Fagus orientalis Lipsky) component of close to nature forestry in northern Iran. Journal of Forestry Research 23 (2): 289-294. - doi: 10.1007/ s11676-012-0254-4

Nosrati K, Marvie-Mohadjer MR, Bode W, Knapp HD (2005). Schutz der Biologischen Vielfalt und integriertes Management der Kaspischen Wälder (Nordiran) [Protection of biodiversity and integrated management of the Caspian forests (northern Iran)]. Bundesamt für Naturschutz, Bonn, Germany, pp. 317. [in German]

Odor P, Van Hees AFM (2004). Preferences of dead wood inhabiting bryophytes for decay stage, log size and habitat types in Hungarian beech forests. Journal of Bryology 26 (2): 7995. - doi: 10.1179/037366804225021038

Parsapajoh D, Schweingruber F (1994). Atlas of woods of Iranian northern forests, University of Tehran Press, Tehran, Iran, pp. 136.

Petritan IC, Marzano R, Petritan AM, Lingua E (2014). Overstory succession in a mixed Quercus petraea-Fagus sylvatica old growth forest revealed through the spatial pattern of competition and mortality. Forest Ecology and Management 326: 9-17. - doi: 10.1016/j.foreco.2014. 04.017

Petritan AM, Biris IA, Merce O, Turcu DO, Petri$\tan$ IC (2012). Structure and diversity of a natural temperate sessile oak (Quercus petraea L.) European beech (Fagus sylvatica L.) forest. Forest Ecology and Management 280: 140-149. doi: 10.1016/j.foreco.2012.06.007

Popescu-Zeletin I, Dissescu R (1967). Classification d'apres la structure des peuplements pluriennes des Carpates roumaines [Classification of the structure of Romanian Carpathians multiannual stands]. In: Proceedings of the "XIV IUFRO Congress". München (Germany) Sep 1967, pp. 4-9. [in French]

Rock J, Badeck FW, Harmon ME (2008). Estimating decomposition rate constants for European tree species from literature sources. European Journal of Forest Research 127: 301-313. doi: 10.1007/s10342-008-0206-x

Rubino DL, McCarthy BC (2003). Evaluation of coarse woody debris and forest vegetation across topographic gradients in a southern Ohio forest. Forest Ecology and Management 183: 221-238. - doi: 10.1016/S0378-1127(03)001087

Saniga M, Schütz JP (2002). Relation of dead wood course within the development cycle of selected virgin forests in Slovakia. Journal of Forest Science 48: 513-528.

Sagheb-Talebi K, Sajedi T, Pourhashemi M (2014). Forest of Iran, a treasure from the past, a hope for the future. Springer-Verlag, The Netherlands, pp. 145.

Sefidi K, Etemad V (2015). Dead wood characteristics influencing macrofungi species abun- 
dance and diversity in Caspian natural beech (Fagus orientalis Lipsky) forests. Forest Systems 24 (2): 2-9. - doi: 10.5424/fs/2015242-06039

Sefidi K, Marvie Mohadjer M R, Etemad V, Mosandl R (2014). Late successional stage dynamics in natural oriental beech (Fagus orientalis Lipsky) stands in northern Iran. Iranian Journal of Forest and Poplar Research 22 (2): 270-283.

Sefidi K, Marvie Mohadjer MR, Mosandl R, Copenheaver CA (2013). Coarse and fine woody debris in mature oriental beech (Fagus orientalis Lipsky) forests of northern Iran. Natural Areas Journal 33 (3): 248-255. - doi: 10.3375/ 043.033 .0303

Sefidi K, Etemad V (2012). The amount and quality of dead trees in a mixed beech forest with different management histories in northern Iran. Biodiversitas 15 (2): 162-168. - doi: 10.13057/ biodiv/d150207

Sefidi K (2012). Late succesional stage dynamics in a mixed beech stands, Northern Iran. PhD thesis, University of Tehran, Tehran, Iran, pp. 178.

Sefidi K, Marvie-Mohadjer MR (2010). Characte- ristics of coarse woody debris in successional stages of natural beech (Fagus orientalis) forests of Northern Iran. Journal of Forest Science 56: 7-17.

Small CJ, McCarthy BC (2002). Spatial and temporal variation in the response of understory vegetation to disturbance in a central Appalachian oak forest. Journal of the Torrey Botanical Society 129 (2): 136. - doi: 10.2307/3088 727

Ter Braak CJ, Smilauer P (1998). CANOCO reference manual and user's guide to CANOCO for Windows: software for canonical community ordination, version 4. Microcomputer Power, Ithaca, NY, USA, p. 351

Urban J, Rebrošová K, Dobrovolny L, Schneider J (2010). Allometry of four European beech stands growing at the contrasting localities in small-scale area, Folia Oecologica 37 (1): 103-111. Valipour A, Namiranian M, Ghazanfari H, Heshmatol Vaezin SM, Lexer MJ, Plieninger T (2013). Relationships between forest structure and tree's dimensions with physiographical factors in Armardeh forests (Northern Zagros). Iranian Journal of Forest and Poplar Research 21 (1):
30-47.

Vrska T, Hort L, Odehnalová P, Adam D, Horal D (2001). The Milesice virgin forest after 24 years (1972-1996). Journal of Forest Science 47: 25527.

Walters GM, McCarthy BC (1997). Forest decline and tree mortality in a southeastern Ohio oakhickory forest. Ohio Journal of Science 97: 5-9.

Yang FF, Li YL, Zhou Gi Wenigmann KO, Zhang DQ, Wenigmann M, Liu SZ, Zhang QM (2010). Dynamics of coarse woody debris and decomposition rates in an old-growth forest in lower tropical China. Forest Ecology and Management 259: 1666-1672. - doi: 10.1016/j.foreco.20 10.01.046

Yin X (1999). The decay of forest woody debris: numerical modeling and implications based on some 300 data cases from North America. Oecologia 121: 81-98. - doi: 10.1007/s004420050 909

Zar JH (1999). Biostatistical analysis (4 $4^{\text {th }}$ edn). Prentice-Hall, Upper Saddle River, NJ, USA, pp. 663. 